\title{
Study of Intrauterine Foetal Death in Government Medical College in Tribal Area of Bastar
}

\author{
Mamta Bansal ${ }^{1}$, Indu Sharma ${ }^{2}$, Somee Chandrakar ${ }^{3}$ \\ ${ }^{1}$ Department of Obstetrics and Gynaecology, Late BRKM Government Medical College, Dimrapal, \\ Jagdalpur, Chhattisgarh, India. ${ }^{2}$ Department of Obstetrics and Gynaecology, Late BRKM Government \\ Medical College, Dimrapal, Jagdalpur, Chhattisgarh, India. ${ }^{3}$ Department of Obstetrics and Gynaecology, \\ Late BRKM Government Medical College, Dimrapal, Jagdalpur, Chhattisgarh, India.
}

\section{ABSTRACT}

\section{BACKGROUND}

IUFD is a major obstetrical complication and is an important indicator of perinatal health in a given population. Literally, intrauterine foetal death (IUFD) is considered as all foetal deaths weighing $500 \mathrm{~g}$ or more occurring both during pregnancy and during labour. We wanted to asses maternal and foetal factors associated with intrauterine death, and formulate effective strategies for prevention of IUFD.

\section{METHODS}

This was a prospective study carried out in a GMC Jagdalpur from July 2019 to midNovember 2019. All the admitted patients of our department with gestational age $>28$ weeks (confirmed by LMP or by USG) diagnosed as having IUFD (confirmed by USG) were included in the study.

\section{RESULTS}

Total number of deliveries during the study was 1455 and total number of IUFD was 109. Incidence of intrauterine death was $7.49 \%$. Majority of the cases were of age group 26-30 years that is $39.44 \%$ (43/109) while teenager $(16-20$ years) pregnancies were only $11.92 \%$. Most of the cases were preterm $(67 / 109)$ around $61.46 \%$ and only $2.75 \%$ cases were post term. In $22.01 \%(24 / 109)$ cases, causes were not identified while in $77.99 \%$ cases $(85 / 109)$ causes were identified. Hypertensive disorder was the major cause of IUFD (27.5\%) followed by unknown aetiology (22.01\%), infection (14.67\%) and rupture uterus (10.09\%). Rural population was $66.97 \%$ and urban population was only $33.02 \%$. Most of the cases were primipara $43.11 \%(47 / 109)$ while least number of cases $8.25 \%(9 / 109)$ was of grand multipara.

\section{CONCLUSIONS}

Despite being a tertiary center, incidence of IUFD is much higher than other areas of our country. Cause may be attributed to lack of awareness, illiteracy, and poor infrastructure in periphery, and this being a referral centre for a large area.

\section{KEY WORDS}

Intrauterine Foetal Death, Hypertensive Disorders of Pregnancy, Rupture Uterus, Unknown Cause
Corresponding Author:

Dr. Indu Sharma,

Quarter No. 6, Type 4,

Residential Colony,

Medical College Campus,

Dimrapal, Jagdalpur, Bastar,

Chhattisgarh, India.

E-mail: georgian.indu@gmail.com

DOI: $10.14260 /$ jemds/2020/489

How to Cite This Article:

Bansal M, Sharma I, , Chandrakar S. Study of intrauterine foetal death in government medical college in tribal area of bastar. J. Evolution Med. Dent. Sci. 2020;9(32):22572260, DOI: 10.14260/jemds/2020/489

Submission 03-03-2020,

Peer Review 01-07-2020,

Acceptance 08-07-2020,

Published 10-08-2020.

Copyright (C) 2020 JEMDS. This is an open access article distributed under Creative Commons Attribution License [Attribution 4.0 International (CC BY 4.0)] 


\section{BACKGROUND}

ACOG defines IUFD as all foetal deaths past 20 weeks weighing 500 gms or more occurring during pregnancy or during labour.(1) Occurrence of IUFD or still birth can cause a nightmare to the parents and treating clinicians. The incidence of IUFD is estimated to be 3 per 1000 pregnancies in developed countries and as high as 45 per 1000 pregnancies in developing countries. Thus ante partum death occurring beyond the period of viability is termed as IUFD. Still birth is an event which remains always challenging for the obstetrician. It is very agonizing for the attending clinician with the feeling of defeat.

The mode of antenatal \& intranatal care is changed in last few decades. There are many clinical maternal and foetal conditions responsible for IUFD \& stillbirth. Thus still birth rate acts as a useful index to measure the adequacy of antenatal as well as intranatal care. In developing countries, major cause of IUFD and still birth are intranatal and avoidable while in developed countries it is antenatal and unexplained. By proper antenatal check-ups along with timely interventions incidence of IUFD is declining for last 2-3 decades. Causes of foetal death include foetal causes (25-40\%), placental causes (25-35\%), maternal causes (5-10\%) and in $25-35 \%$ cases cause remains unknown. The aim of this study is to analyse the maternal as well as foetal conditions causing IUFD and to find out the preventable cause.

\section{METHODS}

This was a single centre retrospective study conducted in GMC Jagdalpur, Bastar, from July up to mid-November 2019. Since the study was retrospective and identities of the patients were treated with full confidentiality and protected, therefore ethical clearance is not needed. No personal data were collected. Total 109 cases of IUFD were taken as study population during this period in tertiary care hospital of Bastar, Chhattisgarh. Data were collected by records on pre structured proforma having details of complaints on admission, obstetric history, menstrual history, P/A \& P/V findings, mode of delivery, and condition of the cord as well as investigation reports.

All the cases of IUFD were confirmed by USG. Based on clinical and pelvic examination induction of labour and mode of delivery was decided. Foetal outcomes were recorded included sex of the baby, birth weight, congenital malformations and birth injuries. Findings of placenta like infarction, calcification and retroperitoneal clot and conditions of the cord like knots, cord around the neck and any other abnormalities were recorded

\section{Inclusion Criteria}

All diagnosed IUFD > 28 weeks of gestation.

\section{Exclusion Criteria}

All abortions were excluded.

\section{Statistical Analysis}

Data was analysed by using simple mathematical addition and percentage.

\section{RESULTS}

During our study period, in our institute, total number of deliveries was 1450 . Out of these 1450 cases, 109 patients were diagnosed and delivered intrauterine dead foetus. We found the frequency of IUFD as 75/1000 deliveries in our institute.

Table 1 shows the demographic characteristics of our study population. In our study maximum number of cases i.e. 43 case of IUFD was seen in 26- 30 years (39.44\%) of age group followed by 39 cases of IUFD in age group of 21-25 years (35.77\%). 13 cases of IUFD were seen in age group of 16-20 years $(11.92 \%)$. Least number of cases i.e. 6 cases $(5.5 \%)$ seen in cases of $>35$ years.

Maximum number of cases i.e. $73(66.97 \%)$ were from rural area and only 36 cases (33.02\%) were from urban area. 62 cases $(56.88 \%)$ of IUFD were seen in multigravida while only 47 cases $(43.11 \%)$ were in primigravida. Among multigravida, majority of IUFD were seen in $3^{\text {rd }}$ gravid (26.18\%) followed by $2^{\text {nd }}$ gravida (17.43\%).

\begin{tabular}{|ccc|}
\hline Age in Years & Number of Cases & $\%$ \\
$16-20$ & 13 & 11.92 \\
$21-25$ & 39 & 35.77 \\
$26-30$ & 43 & 39.44 \\
$31-35$ & 8 & 7.33 \\
$>35$ & 6 & 5.50 \\
Residence & Number of Cases & $\%$ \\
Urban & 36 & 33.02 \\
Rural & 73 & 66.97 \\
Parity & Number of Cases & $\%$ \\
1 & 47 & 43.11 \\
2 & 19 & 17.43 \\
3 & 22 & 20.18 \\
4 & 12 & 11.00 \\
$>4$ & 9 & 8.25 \\
Gestational Age & Number of Cases & $\%$ \\
Preterm & 67 & 61.46 \\
Term & 39 & 35.77 \\
Post Term & 3 & 2.75 \\
Mode of Delivery & Number of Cases & \\
Vaginal & 86 & 78.89 \\
LSCS & 23 & 21.11 \\
\hline Table 1. Demographic Characteristics & \\
\hline
\end{tabular}

\begin{tabular}{|cccc|}
\hline Sl. No. & Causes & No. & \% \\
1. & Unknown & 24 & 22.01 \\
2. & Hypertensive disorder & 30 & 27.5 \\
3. & Infection & 16 & 14.67 \\
4. & Rupture Uterus & 11 & 10.09 \\
5. & Cord Prolapse & 6 & 5.50 \\
6. & Obstructed Labour & 2 & 1.83 \\
7. & Congenital Anomaly & 4 & 3.66 \\
8. & Abruption & 7 & 6.42 \\
9. & Placenta Previa & 2 & 1.83 \\
10. & Post Maturity & 1 & 0.91 \\
11. & Sickle Cell Disease & 3 & 2.75 \\
12. & Anaemia & 2 & 1.83 \\
13. & Meconium & 1 & 0.91 \\
\hline \multicolumn{4}{c}{ Table 2. Causes of IUFD } \\
\hline
\end{tabular}

Most of the cases of IUFD were preterm i.e. 67 (61.46\%) followed by 39 (35.77\%) cases of term gestation. Only 3 cases $(2.75 \%)$ were post term. Maximum IUFD cases were delivered 
vaginally i.e. 86 (78.89\%). Only 23 cases $(21.11 \%)$ were delivered by LSCS.

As table 2 shows, majority of the causes of IUFD were hypertensive disorder i.e. $27.5 \%(30 / 109)$ followed by unknown cause i.e. 22\% (24/109). Infection accounts to $14.67 \%(16 / 109)$. Rupture uterus is also an important cause of IUFD in $10 \%$ of cases $(11 / 109)$. Abruption was seen in $6.42 \%$ cases followed by cord prolapsed in $5.5 \%$. In only 1 case postmaturity, in 2-2 cases placenta previa and obstructed labour was seen. Congenital anomaly was found only in 3.66\% cases.

\section{DISCUSSION}

In our study there were 109 IUFD cases among total 1450 birth, thus the frequency is $75 / 1000$ birth. However, Worldwide the still birth rate is $18.9 / 1000$ birth in 2009 and in western countries it is $4.7-12.0 / 1000$ birth. $(2,3,4,5)$ This is much lower than that observed in our study. The study by Jamal S et al shows incidence 56/1000 birth.(6) In a study done in Uttarakhand, still birth rate was $49 / 1000$ births whereas national average is that of $38 / 1000$ births. (7) The reason for higher incidence of IUFD can be attributed to many causes like lack of inadequate intranatal care, illiteracy, poor awareness regarding women's health as well as low socioeconomic status. Ours is a tertiary care referral centre so all the complicated obstetrical cases are referred here from the periphery \& other centers.

Increased risk of foetal death is present among teenage group and older women. In our study however foetal deaths were more in 21-30 years. This is because most of the women now a days marry after 21 years and in India most of the women complete their family before 35 years. However the study of Jamal $S$ et al and Desai $S$ et al show maximum incidence of IUFD among age group 16-20 years. ${ }^{(6,8)}$ In our study most of the IUD are seen among the cases belong to rural areas than urban areas (67\% vs. $33 \%$ ). This is mainly because our center is located in the remote tribal areas and because of very poor antenatal care, paucity of monitoring facilities in rural areas, lack of trained health personals and late referrals. Sharma $\mathrm{S}$ et al had also observed in their study that $58 \%$ cases of IUFD were from rural areas and only $42 \%$ were from urban areas.(9) Parity of the patients influences the pregnancy outcome. In our study proportion of IUFD was higher in multigravida (57\%). Korde-NV et al observed $51.6 \%$ of multigravida who had still birth.(10) Similarly Raymond E G et al also demonstrated a higher still birth rate in multigravida patients.(11) As our study shows maximum number of IUFD cases in preterm (61.46\%). Similar results were also reported by the study of Jamal et al, Saha D et al and Chitra K et al.(6,12,13) In our study maximum number of cases delivered vaginally (78.89\%) compared to Saha D et al (85.29\%) and Korde NV et al $(73.1 \%)$ and Chitra K et al $(89.4 \%)$ respectively.(12,10,13)

Table 3 of our study shows hypertensive disorder of pregnancy (HDP) to be the cause of maximum number of IUFD (27.5\%). In a study done by Patel S $33.7 \%$ cases showed HDP whereas in the study of Jamal S et al HDP was seen in $41 \%$ of cases and in Saha D et al $20.7 \%$ of cases showed HDP. $(14,6,12)$ In present study unexplained IUFD occurred in $22 \%$ of cases compared to $33 \%$ reported by Neetu Singh et al.(15) In the study of Jamal S et al only $12.5 \%$ cases had no ascertainable cause while in study by Desai S et al $57.69 \%$ of the cases had no definite cause.(6,8) Another important cause of IUFD was infection which was seen in $14.67 \%$ cases comparable to study by Jamal $\mathrm{S}$ et al in which infection attributed to $16.71 \%$ cases and in the study of Garg S et al it was only $5 \% .(6,16)$

We observed rupture uterus as a one of the important cause of IUFD in $10.09 \%$ cases. Being a tribal area poor awareness, illiteracy, injudicious use of oxytocics and late referrals leads to obstructed labour and ultimately rupture uterus. Similar result was also reported by Garg S et al.(16) In placental factors, abruption was found in $6.42 \%$ of cases and placenta previa in $1.83 \%$ cases. Jamal S et al found $30.3 \%$ abruption and $12.5 \%$ placenta previa as a cause of IUFD in his study.(6) Study by Garg S et al showed abruption placenta in $11.25 \%$ of cases.(16) Present study shows cord accidents in $5.5 \%$ cases while other studies shows around 2\% cord accidents. $(7,12)$ Congenital anomaly contributed to $3.66 \%$ of cases in our study compared to the study of Garg S et al which shows congenital anomaly in $5 \%$ cases and of Anjali $\mathrm{C}$ et al $10.5 \%$ cases. $(16,7)$ Patel $S$ et al had observed $2.5 \%$ cases of congenital malformations. ${ }^{(14)}$

\section{CONCLUSIONS}

This study shows higher incidence of IUFD compared to some studies in, our country and many developed countries. Our centre is in a tribal area with illiteracy, poor socioeconomic status, poor health seeking behaviour, late referrals being important factors leading to IUFD. As such all IUFD are not preventable but rate can be brought down by booking of all ANC cases, identification of high risk cases, early referral, and timely intervention. Many of the factors are preventable, can be diagnosed and managed early. Social factors like apathy towards, women's health, decision making, and nutrition, needs to be addressed.

\section{Acknowledgements}

I would like to thank faculty and staff of my department and Maharani Hospital, specially my HOD, Dr Alpana Bansal, for their substantial contributions. I am also very thankful to Dr. Hemant Sharma for his technical support in submission of the article. I would also like to thank all the study participants.

Financial or Other Competing Interests: None.

\section{REFERENCES}

[1] Diagnosis and management of foetal death. ACOG Technical Bulletin no. 176 -January 1993. Intl J Gyncol Obstet 1993;42(3):291-9.

[2] Fretts RC, Boyd ME, Usher RH, et al. The changing pattern of foetal death, 1961-1988. Obstet Gynecol 1992;79(1):35-9.

[3] Lofgren 0, Polberger S. Perinatal mortality: changes in the diagnostic panorama 1974-1980. Acta Paediatr Scand 1983:72(3):327-32. 
[4] Hovatta O, Lipasti A, Rapola J, et al. Causes of still birth: a clinicopathological study of 243 patients. Br J Obstet Gynaecol 1983;90(8):691-6.

[5] Machin GA. A perinatal mortality survey in south east London, 1970-73: the pathological findings in 726 necropsies. J Clin Pathol 1975;28(6):428-34.

[6] Jamal S, Agarwal S. IUFD incidence, causes and complications: a retrospective study done at a tertiary care centre in greater Noida, India. Int J Reprod Contracept Obstet Gynaecol 2017;6(12):5483-7.

[7] Anjali C, Gupta V. Epidemiology of intrauterine foetal deaths: a study in tertiary referral center in Uttarakhand. IOSR Journal of Dental and Medical Sciences (IOSR-JDMS) 2014;13(3):3-6.

[8] Desai S, Savant V. Evaluation of clinical and aetiological factors for intrauterine foetal death. Online Int Interdiscipl Res J 2014;4(1).

[9] Sharma S, Sidhu H, Kaur S. Analytical study of intrauterine foetal death cases and associated maternal conditions. Int J Appl Basic Med Res 2016;6(1):11-3.

[10] Korde NV, Gaikwad P. Causes of still birth. J Obstet Gynaecol India 2008;58(4):314-8.
[11] Raymond EG, Cnattingius S, Kiely JL. Effects of maternal age, parity and smoking on the risk of still birth. BJOG 1994;101(4):301-6.

[12] Saha D, Kurude VN, Mundhe S. A study of intrauterine foetal death in a tertiary care hospital. Int J Reprod Contracept Obstet Gynaecol 2019;8(7):2647-51.

[13] Chitra K, Nitin N, Anuradha K, et al. Intrauterine foetal death: a prospective study. J Obstet Gynaecol India 2001;51(5):94-7.

[14] Patel S, Thaker R, Shah P, et al. Study of causes and complications of intrauterine foetal death (IUFD). Int J Reprod Contracept Obstet Gynaecol 2014;3(4):931-5.

[15] Neetu S, Kiran P, Neena G, et al. A retrospective study of 296 cases of intra uterine foetal deaths at a tertiary care centre. Int J Reprod Contracept Obstet Gynaecol 2013;2(2):141-6.

[16] Garg S, Kumar N. Analysis of factors responsible for intrauterine foetal deaths in rural pregnant women at tertiary care center of Northern India. Int J Reprod Contracept Obstet Gynaecol 2017;6(9):4071-4. 